\title{
Prognostic factors in the development of permanent renal injury in patients undergoing cardiac surgery
}

\author{
C Rodriguez Mejias*, MR Diaz Contreras, L Navarro Guillamon, E Aguayo de Hoyos, A Reina Toral \\ From ESICM LIVES 2015 \\ Berlin, Germany. 3-7 October 2015
}

\section{Introduction}

Renal injury is a frequent and serious complication in patients undergoing cardiac surgery. This injury usually recover completely. However, according to recently published data, a significant number of patients with this lesion remain at hospital discharge.

\section{Objective}

To analyze patients undergoing cardiac surgery in our hospital to determine whether there prognostic factors for the development of permanent kidney damage.

\section{Methods}

We use data base Andalusian registry of cardiac surgery in the comprehensive care plan to heart disease, referring to patients operated in our hospital and admitted to our intensive care unit of the" Hospital Virgen de las Nieves" of Granada, between June 2008 until the end of 2014.

\section{Results}

A total of 2,443 patients underwent cardiac surgery and discharged from hospital alive. Of these 1,497 had prior to surgery normal renal function (defined by plasma creatinine $\leq 1.2 \mathrm{mg}$ ). A total of 149 were discharged with plasma creatinine levels that exceeded $0.3 \mathrm{mg}$ baseline and / or an increase of $50 \%$ of these values, regardless of what happened during their hospital stay.

The main baseline characteristics of patients with and without renal injury were (table 1 )

By adjusting a model of binary logistic regression (table 2) with the variables age, diagnostic group, NYHA class, character surgery, COPD (cronic obstructive

Granada University, ICU Complejo Hospitalario, Granada, Spain
Table 1

\begin{tabular}{llllll}
\hline & No (1678) & \multicolumn{5}{c}{ Yes (149) } \\
\hline & \multicolumn{1}{c}{ Media } & sd & Media & sd & $\mathbf{p}$ \\
\hline Age & 61,44 & 13,59 & 67,30 & 10,64 &, 000 \\
\hline Preoperative creatinine &, 89 &, 17 &, 86 &, 19 &, 05 \\
\hline Ejection fraction & 59,25 & 10,52 & 57,43 & 11,07 &, 04 \\
\hline CPB time & 112,37 & 45,91 & 108,14 & 42,94 &, 3 \\
\hline Aortic clamp time & 85,61 & 38,33 & 86,09 & 38,47 &, 88 \\
\hline Discharge creatinine &, 80 &, 20 & 1,49 &, 77 &, 000 \\
\hline EuroSCORE Log & 6,94 & 7,85 & 9,55 & 11,38 &, 000 \\
\hline
\end{tabular}

Table 2

\begin{tabular}{llllll}
\hline & No $\mathbf{n}$ & No $\%$ & Yes $\mathbf{n}$ & Yes $\%$ & $\mathbf{p}$ \\
\hline Diabetes & 415 & 25,00 & 56 & 38,10 &, 001 \\
\hline COPD & 151 & 9,10 & 24 & 16,30 &, 008 \\
\hline NYHA:I & 473 & 28,20 & 29 & 19,50 &, 002 \\
\hline II & 700 & 41,80 & 53 & 35,60 & \\
\hline III & 439 & 26,20 & 57 & 38,30 & \\
\hline IV & 64 & 3,80 & 10 & 6,70 & \\
\hline Type: Emergent & 32 & 1,90 & 5 & 3,40 &, 25 \\
\hline Scheduled & 1448 & 86,30 & 122 & 81,90 & \\
\hline Urgent & 198 & 11,80 & 22 & 14,80 & \\
\hline
\end{tabular}

pulmonary disease), Diabetes, ejection fraction and EuroSCORE is obtained that the variables that are significantly associated with the development of renal injury are age (most significant), COPD and NYHA class.

\section{Conclusions}

Age, having COPD or NYHA class to undergo cardiac surgery, are prognostic factors for the development of 
permanent renal injury. These factors should be considered in risk stratification prior to surgery.

Published: 1 October 2015

doi:10.1186/2197-425X-3-S1-A14

Cite this article as: Rodriguez Mejias et al:: Prognostic factors in the development of permanent renal injury in patients undergoing cardiac surgery. Intensive Care Medicine Experimental 2015 3(Suppl 1):A14.

\section{Submit your manuscript to a SpringerOpen ${ }^{\circ}$ journal and benefit from:}

- Convenient online submission

- Rigorous peer review

- Immediate publication on acceptance

- Open access: articles freely available online

- High visibility within the field

- Retaining the copyright to your article

Submit your next manuscript at $\gg$ springeropen.com 